\title{
EU INTEGRATED POLITICAL CRISIS RESPONSE SYSTEM WITHIN THE SCOPE OF THE EU COMMON SECURITY AND DEFENCE POLICY: THE ROLE OF NEGOTIATION AS INSTRUMENT TO MANAGE CRISIS
}

\author{
Rasa VEGIENE் ${ }^{1}$, Edita LEONAVIČIENE் 2* $^{*}$ \\ ${ }^{1}$ General Jonas Žemaitis Military Academy, Šilo g. 5, LT-10322 Vilnius, Lithuania \\ ${ }^{2}$ Department of Business Technologies and Entrepreneurship, Faculty of Business Management, \\ Vilnius Gediminas Technical University, Sauletekio al. 11, LT-10223 Vilnius, Lithuania
}

Received 28 February 2021; accepted 01 April 2021

\begin{abstract}
Purpose - examine the European Union (EU) integrated political crisis response system, within the scope of the EU common security and defence policy and the present value of negotiations as a tool.

Research methodology - a systematic analysis of the scientific literature and descriptive methods were applied to analyse actual and recent theoretical scientific work on integrating the European Union security and defence policy. We were discussing the concept of security from the theoretical perspective of constructivism, presenting the essential features. The empirical part of the work proves how discourse theory may help develop both negotiations and constructivism methodology.
\end{abstract}

Findings - Negotiation theory play an important role in crisis management, developed proposals for the theory and methodology of negotiations.

Research limitations - research does not cover negotiations in the context of military actions; the research examines the only civil empirical case of COVID-19 crises.

Practical implications - presented conclusions show how the development of negotiations theory may substantially increase responsiveness to any EU crisis.

Originality/Value - this study as interdisciplinary combined mixed methodologies: constructivism methodology of threat identification was compared with discourse theory (Austin's) speech act.

Keywords: negotiations, constructivism, security, crisis management, crisis response system.

JEL Classification: M14, M 16, K20.

Conference topic: Business Processes: Development, Digitalization, Social Responsibility.

\section{Introduction}

National and EU authorities need to take quick decisions to manage the COVID-19 pandemic crisis. The global coronavirus pandemic has disrupted many aspects of everyday life. Many in the public sector institutions working in the EU Integrated Political Crisis Response system became the front lines dealing with that enforcement on EU and member states governmental level decisions. This article aims to examine the role of the negotiations during the COVID-19 pandemic in protecting economic activities suffering imposed restrictions as a tool used by the EU Integrated Political Crisis Response System within the scope of the EU Common Security Defense Policy (CSDP). This essay examines relations between many institutions forming the EU integrated Political Crisis Response System during the pandemic. It describes the impact of negotiation processes used to protect the health of EU citizens and the balance of economic restrictions and preservations. Conflict management, reform of national crisis response systems and find possibilities to reform and strengthen both CSDP management and negotiations theory.

Authors suggest that useful negotiations management theory and practice may play an important role in crisis management. In this context was described the EU integrated political crisis response system. The scope of the EU CSDP unleashes the importance of negotiation theory and the benefits of this methodology. They are making the

*E-mail: Edita.leonaviciene@vilniustech.lt

(C) 2021 Authors. Published by Vilnius Gediminas Technical University. This is an open-access article distributed under the terms of the Creative Commons Attribution (http://creativecommons.org/licenses/by/4.0/) License, which permits unrestricted use, distribution, and reproduction in any medium, provided the original author and source are credited. 
necessary, effective decisions to manage the crisis on a political level, ensuring the health and safety of EU citizens. EU Integrated Political Crisis Response system is formed by EU CSDP response. Some negotiations have more benefits in turning to long-term aims. It ensures that decisions are based on a proper analysis, focusing on delivering stabilisation and peace to the conflict-sensitive response.

As a result, conclusions lead to show how the development of negotiations theory and methodology may help achieve a substantial increase in responsiveness to any EU crisis. Also, it may help develop better $a d-h o c$ decision-making during any emergencies.

Negotiations as an instrument of decision-making, especially in crisis times, also need to use interdisciplinary methods and methodologies. The wisdom of negotiation and forming the political process securitisation theory is to be applied. The legalisation of made decisions requires Austin's (rational discourse) speech theory, mainly used in legal reasoning. The article presents general recommendations for actors engaged in negotiations during times of crisis.

In the theoretical part of the work: a systematic analysis and descriptive methods are applied to discuss security from the theoretical perspective of constructivism, presenting the essential features. The empirical part of the work combines several methods: descriptive, analytical, and comparative methods. Reveal the peculiarities of the development and the dynamic nature of the negotiations as a tool for ensuring the Political Crisis Response System in EUCSDP. The chapter also analyses the most crucial role of negotiations. It states that important keynotes for managing negotiations also reveal a tight connection between two methodologies: constructivism and Austin's theory of speech. Rules, the methodology of rational discourse may be used for negotiations theory and suggest a direction for constructivism on how to solve one of the most argued aspects of this theory.

\section{The COVID-19 pandemic - civil crisis causing security challenges and need for negotiation}

COVID-19 pandemic is a civil crisis on the state's level (defined as civil emergency level). Because of the worldwide spread of disease, it became a worldwide civil crisis. To manage this crisis by the efforts of one state is not enough. As a global actor in building security, the EU promotes the prevention and resolution of conflicts to support peace worldwide and acts as a coordinator between the EU member states.

All member states faced current issues due to several restrictions: social distancing, reducing density, working remotely, teaching online, and creating many issues for the political decision-making process; these can be solved using negotiation as an instrument. Some became feeling and declaring being not safe (not only persons but also types of businesses, economic activities). To build security, we need to understand what it is and who are the main players/builders of security.

\subsection{EU - security actor}

The EU Global Strategy consist of security, development, and diplomatic actions in support of common objectives. The EU seeks to ensure an integrated approach to crises by using the comprehensive toolbox at the EU disposal - at all stages, from prevention to crisis management - in order to contribute to security both global and internal (Backman \& Rhinard, 2018). On a global level, the EU has developed an EU external action service (EEAS) that implements the Common Security and Defence Policy (CSDP). CSDP enables the EU to take a leading role in peacekeeping operations, conflict prevention, and the strengthening of international security. It is an integral part of the EU's comprehensive approach towards crisis management, drawing on civilian and military assets (Brown \& Marcum, 2011a). One of the tools to manage the crisis is mediation, diplomacy, and of course - negotiations (Barnett et al., 2001; Blondin \& Boin, 2020). The EU delivers stabilisation and manages crisis in close coordination with the Member States, combining conflict prevention, mediation, and peacebuilding effectively (Ansell et al., 2010). The EU is also working to develop civilian capabilities and enhance the responsiveness of civilian crisis management. Including the possible creation of a core responsiveness capacity (EU Cooperation on Security and Defence - Consilium, 2016). The EU ensures that EU engagements are conflict-sensitive and based on proper analysis. Concerning crisis prevention, the EU uses relevant policies, tools, and instruments quickly and sequentially. The EEAS is actively involved in mediation, mediation support activities, and dialogue to support the EU's efforts to preserve security at any stage of the crisis cycle (Benedikt et al., 2020; Blondin \& Boin, 2020).

The European Union (EU) has been evolving for fifty years, and this process has been based on negotiations and compromise. Efforts to make conflict and crisis prevention a political priority for the EU after the Cold War have been hampered by institutional development. The EU has now acquired the capacity for political expertise, planning and analysis, operational mechanisms, as well as the strategic goal of external action. Conflict and crisis prevention is a process that includes: long-term or structural policies, analysis of the causes of conflict, preventive diplomacy and civilian/military crisis management. Conflict prevention policy covers the EU's external economic competencies, development and humanitarian aid, and the Common Foreign and Security Policy (CFSP) and the CSDP). Crisis prevention stems from structural policies to address the root causes of conflicts, require early warning and planning/ analysis expertise, and short-term civilian and military crisis management (operational). The EU has mechanisms in place to help prevent external crises and conflicts in each of these areas. 
An analysis of these EU mechanisms shows that different institutions with different approaches and decision-making procedures have been involved in developing conflict prevention policies. European Commission and the EU Council response to crises. Complicates policy planning and formulation, requires sufficient dialogue, negotiation, coordination and common goals.

The development of a coordinated crisis prevention policy at the EU level poses challenges due to fragmentation across institutions. Lack of internal coordination, governance and negotiation results in the EU's reputation and influence as an international actor declining. The EU's ability to coordinate crisis prevention with international organizations: The United Nations (UN), the Organization for Security, the Cooperation in Europe (OSCE)) can be diminished. Addressing these issues and using negotiations could help the EU to contribute more effectively to international conflict and crisis prevention.

\subsection{The concept of security}

The constantly changing security environment makes it necessary to redefine the concept of security again and again. This concept has got a wide variety of interpretations. Due to the dynamic security environment $\mathrm{s}$ and changes in the international environment, security is defined differently in different periods, acquiring transformations (Baele $\&$ Thomson, 2017). Historically the concept of security was linked to the state from the Treaty of Westphalia. The state, using its authority, decides what security means for it. Theories prevailed: idealism, realism, neoliberalism, and constructivism. The security ideas of this theory were evaluated and changing. The traditional approach to security prevailed before and during the Cold War. It focuses on the national interests of the state and the protection of threats. Since the end of the Cold War, the debate on security has expanded to include economic security, environmental security, food security and human security.

This article focuses on the theoretical approach of constructivism. The theory of constructivism (often seen more as an analytical approach to international relations than an independent theory) has proposed a human security approach (Balzacq et al., 2015). Threats arise from internal processes (interactions of individuals) in different states. In our article, attention lays on the crisis caused by COVID-19, which imposed a threat to the health of individuals. During this crisis, every individual's main threat was health, which expanded to national and international levels. Constructivism seeks to examine security at the individual level with less emphasis on state influence. Negotiations as an instrument to manage crisis seek to find solutions. Without a discourse process between crisis management players, it not possible to find balancing solutions (Donohue, 2015).

To the extent understood as discourse, negotiations can take a detailed look at rational discourse theory: Austin's theory of speech, enriching and enabling the negotiations. Constructivism also focuses on perceptions and the discourse that may help build new negotiation theory and practice approaches. Our primary concern is security, building it, and reaching a common understanding of security issues.

\section{Constructivism theoretical approach}

The theory of constructivism is applied to various social management, security, and political phenomena research. When analysing the problems of international relations, objective economic, defensive capacity, the mentality, culture, values, or even the role of power is considered significant in the theory of constructivism. The concept of a company's security occupies an essential place in the theory of constructivism. Standard norms, mutual trust, values, and symbols form a community (collective) identity (Barnett et al., 2001).

Representatives of this theory Emmanuel Adler and Alexander Wendt sought to broaden the understanding of the world model formed by the theory of realism and present new analysis models. State security (national security) proved to be insufficient. The aim was to replace state security with a broader security concept. They were supplementing it with various elements, such as security of people, the security of individuals, or global and international communal security (McDonald, 2008). The novelty of constructivism is the aim to establish a broader approach to ensuring the security of individuals. These are military factors determined by the state and economic prosperity, environmental protection, cultural identity, political rights, health and more.

Constructivist security studies are based on the assumption that the fundamental structures of international politics are socially constructed. This approach enables examining the system, helping improve safety, and understanding that the system. From this point of view, it is possible to see the system and the process, actors, interests, and taking into account this wide variety to manage these interests through negotiations.

Researchers Buzan, Wæver, and Wilde (1998) created Copenhagen School of Constructivism, focusing on the following key concepts: 1) security, 2) sectors, 3) regional security complexes. Security understood as an existential threat that requires finding solutions to eliminate it. Identifying the security object, they depend on the security actor. Security player is considered the state with a historically privileged position and is best placed to perform security tasks. When considering security and de-security issues, theorists implicate the idea that security measures are the most appropriate way to address security issues (Buzan et al., 1998). The author's view complements this idea that security meanings cannot be objectively defined because they are subjective. 
This viewpoint is discussed very often. The political process of threat identification usually uses common perceptions of auditorium/international or national relations actors. The naming threat is not enough. The public has to understand and agree that it is a threat. From one side, the naming threat has to use expressions, evidence acceptable to the public. On another side, the public has to share the same interest to preserve the object from identified threats (Floyd, 2020). So, the actor - community, population, or any group of interests or state- is formed as identity, unified by shared values and perceptions, described mainly by social context. The concept of security communities occupies mane place in the theory of constructivism. Standard norms, mutual trust, values, and symbols form a community (collective) identity (Barnett et al., 2001). Thus, the basis of collective security is the intangible processes or meanings shared by the elements involved (such as states or individuals) that affect state structures and larger collective security structures. These take over specific meanings and values and continue to spread and consolidate until they are universally healed (Kuipers \& Boin, 2015). Emanuel Adler supports this idea by arguing that individuals and social actors give meaning to the material world and cognitively shape the world as known, experienced, and understood (Adler, 1997). The most discussed focus of constructivism theory is the act of speech, where someone states smith as being a threat, and the audience agrees or not with that statement (Huysmans, 2011). The next step is a political response. Here the negotiation is used on both stages - threat identification and response to its management.

We presenting Austin's theory of an acts of speech, as one of the theories of practical discourse. Austin's theory's primary focus on a speech: acts of speech are actions done saying smith (White, 1963). For example, if I say: "I promise, I will come tomorrow", I am not only saying but also making a statement. According to Austin, it is always possible to find several functions of the act speech: elocutionary, illocutionary, and perlocutionary. The theory of Austin is older than constructivism. The philosophical basis of Austin's theory of an act of speech can enrich both constructivism and the theory of negotiations by providing more detailed discourse management rules. Especially in crisis negotiations (as an instrument of decision making) need to use interdisciplinary methods and methodologies. During the political process, securitisation theory and legalisation of made decisions, it is required to apply rational discourse theory (especially in naming threats, choosing responses to security issues and legal reasoning of these).

\section{Research methodology}

For this article, several methods of scientific analysis were chosen: analytical descriptive and comparative. The choice of each method chosen to analyse the topic of the work and implement the research is to set goals and objectives. In the theoretical part of the work, descriptive methods are applied to analyse the integration of the EU security and defence policy, discussing security from the theoretical perspective of constructivism, presenting its essential features. The consistent application of the analytical method allows revealing the peculiarities of the development of the unified security and defence policy of the EU.

The empirical part of the work combines descriptive, analytical, and comparative methods. They reveal the peculiarities of the development and the dynamic nature of the negotiations as a tool for ensuring the Political Crisis Response System in the EU. The chapter also analyses the most crucial role of negotiations. It states important keynotes for managing negotiations and reveals the tight connection between two methodologies: constructivism and Austin's theory of an act of speech. The methodology of rational discourse may be beneficial for negotiations theory and suggest a direction for constructivism on how to solve one of the most argued aspects of this theory. The legalisation of decisions on a political level after reasonable and acceptable discourse, sometimes after negotiations, impacts the EU Integrated Political Crisis Response System.

\section{EU integrated political crisis response system: the role of negotiations}

The main objective of the European External Action Service (EEAS) under the Lisbon Treaty is to increase the response to challenges, which is a fundamental principle of the provisions of the Lisbon Treaty (Kaplanova, 2016). Appropriate EU action in emergencies, where $a d$ - hoc decisions are required, is no exception (Kuipers et al., 2015). Crisis response implies the immediate mobilisation of EU resources to deal with the consequences of external crises caused by human-made and natural disasters, as is the COVID-19 pandemic.

\subsection{EU integrated political crisis response system institutions}

The EEAS Crisis Response and Operational Coordination Department are responsible for activating the EEAS Crisis Response System (Crisis Platform, EU Situation Room, Crisis Management Board). It, therefore, plays a crucial role in ensuring the rapid and effective mobilisation of actors and instruments across the EU framework and the coherence of policies and actions at different stages of the crisis life cycle.

The EEAS Crisis Response System (CRS) covers all crises that may affect EU security and interests outside and inside the EU. It equally covers crises within the EU if they have an external dimension. CRS ranges from prevention and preparedness to response and recovery to achieve a comprehensive EU crisis response and management capacity. 
CRS contributes to ensuring coherence between different aspects of crisis response and management, particularly in security, politics, diplomacy, consular, humanitarian, development, space, environment, and enterprise. The secretariat of the CRS is ensured by the EEAS Crisis Response Department, which plays a critical coordinating role that facilitates translating the comprehensive approach into comprehensive action in crisis response and management (Brown \& Marcum, 2011a; Goniewicz et al., 2020).

\subsection{EU crisis management measures}

Unfortunately, different institutional and decision-making processes are used to respond to and manage crises. Effective coordination of crisis management measures is always essential for timely and effective crisis response.

Crisis management requires coordination. During the crisis, all key players are invited to ensure coordination during the EU Presidency. The following tools required to be used: information sharing facilitated cooperation, coordinated crisis response. But, without negotiations, this cannot be guaranteed.

Key players, including the Commission, EU agencies, the most affected Member States, the Cabinet of the President of the European Council, use an informal roundtable, analytical reports, online platforms and a 24-hour contact point. There are three types of operating modes, depending on the situation: monitoring, information sharing and complete activation. In the case of the COVID-19 crisis, the entire activation regime was announced on 2 March 2020.

The full activation regime turned on the development of coordinated EU responses in Presidency-led roundtables with the Commission's participation, the EEAS, the Office of the President of the European Council, affected Member States, relevant EU agencies and experts. The ability to conduct effective negotiations serves to implement all the principles of emergency management:

- Completeness - taking into account all hazards, stakeholders and consequences of disasters.

- Graduality - preparatory measures to build disaster-resilient communities.

- Risk - priorities are identified based on hazard identification, risk and impact analysis.

- Integration - an easily united effort at all levels of government with the entire community.

- Collaboration - maintain relationships between individuals and organisations when we trust, seek team atmosphere and consensus.

- Coordination - the activities of all stakeholders must be synchronised for a common goal.

- Flexibility - creative methodological serves to solve problems.

- Professionalism - a solution based on science and knowledge (education, training, experience, ethical practice, public oversight).

The other negotiations tools to be used: interoperability of crisis management stakeholders, complete authority over development infrastructure, the integrated emergency management plan, and activated non-governmental actors at all stages of crisis management.

The crisis management platform consists of various services/activities across the EU. It is activated on $a d-h o c$ basis. The platform guides the EEAS and the Commission services on how to deal with the crisis. Depending on the specific crisis, the Crisis Platform may have the necessary management structures: Crisis Management and Planning Directorate, Crisis Response Department, EU Military Staff, Civilian Planning and Conduct Capability, Situation Center, EU Situation Room and relevant departments and European Commission services (Blondin \& Boin, 2020).

\subsection{Crisis response cycle}

Emerged the crisis of COVID-19 requires swift responses to alleviate human suffering, prevent further escalation, promote dialogue and protect EU citizens. The capacity of the EU to meet the needs and challenges that arise in natural emergencies depends on its ability to make decisions. In short, when crises erupt - immediate attention and coordination are required. Without negotiations during the crisis response cycle, it is impossible to achieve (Brown \& Marcum, 2011b). The EU crisis response cycle aims to build measures and a comprehensive approach, which covers conflict prevention, peacebuilding, CSDP missions, and development programs (Brown \& Marcum, 2011b).

\section{The benefits of negotiations for the $\mathbf{E} \mathrm{U}$ crisis response system}

Measures that can help alleviate the spread of the virus and manage this crisis include individual behaviour and routine change (stay at home, social distance, remote working, the need to wear a mask, restrictions on mobility). Also, the publications of expert, scientific coronavirus research. All of this together requires more organisational and state systemic change and private life and business change.

Any changes in people naturally cause stress. Some individuals have developed resilience and have psychological flexibility. It is expected that people often resist changes because it is natural to stay in a more comfortable comfort zone. Changes provoke conflicts, and during crisis management, they make it difficult to motivate for the necessary changes. Therefore, good negotiation skills are essential. Negotiation principles can help the parties make the neces- 
sary changes. During the management of COVID-19, the public had to be convinced on scientific research about the necessary social distance, personal protective equipment (masks, disinfectants).

In crisis management, the achievement of political consensus requires the use of principles of negotiations and keeping in mind when people are experiencing gradual change. To this end, decisions must motivate and rely on those who adapt quickly to change, help those who go through the stages of denial before adaptation, and negotiate flat sources of information.

Principles of negotiation theory are to be used in Crisis Management: emphasis of (security of health) interest, aiming for objectivity (anticipating and decontaminating possible cases). Crisis negotiations often require multilateral negotiations when agreements are reached (Donohue, 2015).

Being familiar with the EU crisis response system, knowing the steps of crisis management helps to build awareness for the situation, initiate problem solutions in time, and to prevent the interests of any group (at the national or private sector level) (Kaplanova, 2016).

Negotiations are the tool to make decisions, solve conflicts, balance competing interests. To benefit the negotiations, recommendation to use the tools to manage a crisis:

1. The initiation of negotiations immediately. Early success can help to avoid conflict prolongations and may help future negotiations. The absence of negotiations and communications leads to unilateral decision-making without consultations. That could be the reason why will be needed retroactive tries to combat problems, which with timely negotiations could have been circumvented.

2. Mobilise security actors, their workforce. During the COVID-19 crisis, a physical presence not possible. All actors in the crisis management system needed to find other forms of mobilisation to represent their interests during negotiations and ensure social distancing. They needed to create visibility of theirs. It has the impact of negotiations strategy - to include all parties into the process.

3. Prioritise issues for the most affected by the crisis, prepare a comprehensive evaluation. It is necessary to ensure negotiation strategies. Usually, all states in their security strategies, legislative acts have norms, giving priority to secure the state's interests to personal rights. If arguments provide for the state's security (implementation of EU directives), it may help win negotiations. So, think about arguments, having a double positive effect for both negotiating parties.

4. Consider Legislative Level Crisis Response in Negotiated Protections. During the COVID-19 crisis, financial impacts remain unknown and unpredictable across many various sectors and economic activities. However, most likely, the effects will last for years.

5. Formalise impact of negotiated agreements. Reached decisions during negotiations need to be formalised, documented. Only these forms of decisions may become references for the following legalised decisions.

This article aims to unleash the importance of negotiation theory and the benefits of this methodology in making the necessary, effective decisions to manage the crisis on a political level, ensuring the health and safety of EU citizens.

\subsection{The benefits of discourse theory for negotiations}

Development of negotiations theory and methodology may help achieve a substantial increase in responsiveness to any EU crisis. It may help to develop better $a d$ - hoc decision-making during any emergencies. Negotiations, as an instrument of decision-making, need to use interdisciplinary methods. Current issues of policies need not only management knowledge but also the wisdom of negotiation. Formation of the political process, legalisation of made decisions requires application of rational discourse theory.

We have already disclosed how discourse methodology is connected with constructivism methodology. Negotiations, as an instrument of decision-making, need to use interdisciplinary methods. Current issues of policies need not only management knowledge, the wisdom of negotiation. Formation of the political process, legalisation of made decisions requires application of rational discourse theory. Let take a more detailed look at the speech acts theory. Speech act theory is the theory of meaning that holds the meaning of linguistic expressions. Can be explained in terms of the rules governing their use in performing various speech acts (e.g., admonishing, asserting, commanding, exclaiming, promising, questioning, requesting, warning). A critical area of pragmatics is speech acts, which are communicative acts that convey an intended language function. Speech acts include functions such as requests, apologies, suggestions, commands, offers, and appropriate responses to those acts (Brown, 2019; Elbasan, 2017).

When COVID-19 virus was announced as causing the threat, the audience was agreeing or not. Crisis management needed that population agree on the fact that virus is a threat. Negotiations seek to make agreements. Austin's theory's central part is that the act of speech is an act of agreement. This theory is meaningful because:

1. Clarifies what the use of any language is a rule-based activity;

2. Shows the fact that the use of normative language does not differ from the use of descriptive language;

3. Presents a system of basic concepts that contribute to productive discourse. 
Already we have mentioned that Austin presented the concept of illocution. The illocutionary act can be a declaration, command or a promise. A perlocutionary act (e.g., a listener's reaction) is the perlocutionary result (how the promise reacts) (Hidayat, 2016). It might be acceptance, scepticism, or disbelief, but none of these reactions alters the illocutionary force of the statement: the promise was made.

In the negotiations, we need to form an illocutionary act, which creates a positive perlocutionary act in response. Naming any object as a threat (COVID-19 pandemic threatened lives and health of people worldwide) has to be perceived, accepted as a threat by the audience. Constructivist criticised because of the weakness of their methodology causal connection between the act of speech and response to it. We conclude that both constructivist and negotiation theories may benefit and develop by using discourse theories. The proposals for the constructivism theory are out of the scope of this research. As a result of the analysis of the negotiations used as a tool to manage the COVID-19 crisis, this article discloses the possibilities to develop negotiations theory using the methodology of the discourse theory.

\section{Conclusions}

This article describes the role of the negotiations that were used and could be used for a better EU Integrated Political Crisis Response system, formed by EU CSDP response. It is also noted that some negotiations ambush to avoid and have more benefits. The balance of needs and expenses, avoiding fear-drawing alternatives but turning to long term aims. Ensure that decisions are based on a proper analysis, focusing on delivering stabilisation and peace and conflict-sensitive response. The negotiations are the tool to influence public policy and to implement decisions. The negation process aims to conclude solutions that de-conflict contradicting interests. In this aim, a formed rational discourse and used negotiations as a tool in a crisis.

Most negotiated responses to the crisis share one feature: they assume that the crisis is a temporary phenomenon and, therefore, present temporary solutions. The fact is that the crisis continues for a year. During this crisis, negotiations helped to adapt persons and business entities to new problem solving - changing working in an office to remote, zero tolerance to a person with any illness in office. Although this is now seen as a temporary and necessary practice, it may well prove to be irreversible in the future.

COVID-19 crisis is still increasing the pressure on both political leadership and private business in the negotiation process. Public leaders must respond quickly and strategically to balance the threat of the disease's spread and economic activities. The impact of negotiations can affect countries and people's lives for a long, even after the crisis. We have identified several strategies to increase the likelihood of successful negotiations during crises, such as COVID-19.

In crisis management during negotiations, this article proposes that before identifying the threat, the actor need to think precisely and use the logical rules of Austin's (discourse) theory: formulate an illocutionary act in such a manner, which can create a perlocutionary act in response. Only in this case, the positive political response can be predicted because of an established causal connection between the act of speech and response to it. If, during discourse, the statement (an illocutionary act) formed without the possibility of making an acceptable positive response (perlocutionary act), no chances to win the negotiations or manage the crisis without a hostile population's response.

This article proved the importance of negotiation theory and the benefits of this methodology in managing the crisis. We conclude that both constructivist and negotiation theories may benefit and develop by using logical conclusion making rules of discourse theories. However, the proposals for the constructivism theory are out of the scope of this research.

\section{Disclosure statement}

We declare that we do not have any competing financial, professional, or personal interests from other parties.

\section{References}

Adler, E. (1997). Seizing the middle ground: Constructivism in world politics. European Journal of International Relations, 3(3), 319-363. https://doi.org/10.1177/1354066197003003003

Ansell, C., Boin, A., \& Keller, A. (2010). Managing transboundary crises: Identifying the building blocks of an effective response system. Journal of Contingencies and Crisis Management, 18(4), 195-207. https://doi.org/10.1111/j.1468-5973.2010.00620.x

Backman, S., \& Rhinard, M. (2018). The European Union's capacities for managing crises. Journal of Contingencies and Crisis Management, 26(2), 261-271. https://doi.org/10.1111/1468-5973.12190

Baele, S. J., \& Thomson, C. P. (2017). An experimental agenda for securitization theory. International Studies Review, 19(4), 646-666. https://doi.org/10.1093/isr/vix014

Balzacq, T., Guzzini, S., Williams, M. C., Wæver, O., \& Patomäki, H. (2015). What kind of theory - if any - is securitization? International Relations, 29(1), 96-136. https://doi.org/10.1177/0047117814526606 
Barnett, R. V, Adler, A., Easton, J., \& Howard, K. (2001). An evaluation of peace education foundation's conflict resolution and peer mediation program. School Business Affairs, 67(7), 29-39. https://eric.ed.gov/?id=EJ636957

Benedikt, A., Susło, R., Paplicki, M., \& Drobnik, J. (2020). Mediation as an alternative method of conflict resolution: A practical approach. Family Medicine and Primary Care Review, 22(3), 235-239. https://doi.org/10.5114/fmpcr.2020.98252

Blondin, D., \& Boin, A. (2020). Cooperation in the Face of Transboundary Crisis: A framework for analysis. Perspectives on Public Management and Governance, 3(3), 197-209. https://doi.org/10.1093/ppmgov/gvz031

Brown, J. N., \& Marcum, A. S. (2011a). The Common Security and Defence Policy (CSDP). European external action service. https://eeas.europa.eu/topics/common-security-and-defence-policy-csdp/431/common-security-and-defence-policy-csdp_en

Brown, A. (2019). African American enslavement, speech act theory, and the law. Journal of African American Studies, 23(3), 162-177. https://doi.org/10.1007/s12111-019-09431-z

Brown, J. N., \& Marcum, A. S. (2011b). Avoiding audience costs: Domestic political accountability and concessions in crisis diplomacy. Security Studies, 20(2), 141-170. https://doi.org/10.1080/09636412.2011.572671

Buzan, B., Waever, O., \& Wilde, J. (1998). Security - A new framework for analysis. Lynne Rienner Publishers. Inc. https://www. academia.edu/39047709/Buzan_Waever_and_De_Wilde_1998_Security_A_New_Framework_For_Analysis

Donohue, W. A. (2015). Crisis negotiation. In The international encyclopedia of interpersonal communication, (pp. 1-9). John Wiley \& Sons. https://doi.org/10.1002/9781118540190.wbeic176

Elbasan, A. (2017). Analysis of speech acts in political speeches. European Journal of Social Sciences Studies, 2(2), $19-26$.

European Council. (2016). EU cooperation on security and defence - Consilium. https://www.consilium.europa.eu/en/policies/ defence-security/

Floyd, R. (2020). Securitisation and the function of functional actors. Critical Studies on Security, 1-17. https://doi.org/10.1080/21624887.2020.1827590

Goniewicz, K., Khorram-Manesh, A., Hertelendy, A. J., Goniewicz, M., Naylor, K., \& Burkle, F. M. (2020). Current response and management decisions of the European Union to the COVID-19 outbreak: A review. Sustainability, 12(9), 3838. https://doi.org/10.3390/su12093838

Hidayat, A. (2016). Speech Act: Force behind words. Jurnal Tadris Bahasa Inggris, 9(1)(1), 1-12. http:ejournal.radenintan.ac.id/ index.php/ENGEDU

Huysmans, J. (2011). What's in an act? On security speech acts and little security nothings. Security Dialogue, 42(4-5), 371-383. https://doi.org/10.1177/0967010611418713

Kaplanova, P. (2016). The European crisis management: An organizational narrative. Acta Universitatis Danubius. Relationes Internationales, 9(2), 5-21. http://journals.univ-danubius.ro/index.php/internationalis/article/view/3772/3792

Kuipers, S., \& Boin, A. (2015). Exploring the EU's role as transboundary crisis manager: The facilitation of sense-making during the ash crisis. In R. Bossong \& H. Hegemann (Eds), New Security Challenges Series. European Civil Security Governance (pp. 191-192). Palgrave Macmillan. https://doi.org/10.1057/9781137481115_9

Kuipers, S., Boin, A., Bossong, R., \& Hegemann, H. (2015). Building joint crisis management capacity? Comparing civil security systems in 22 European Countries. Risk, Hazards \& Crisis in Public Policy, 6(1), 1-21. https://doi.org/10.1002/rhc3.12070

McDonald, M. (2008). Securitization and the construction of security. European Journal of International Relations, 14(4), 563587. https://doi.org/10.1177/1354066108097553

White, A. R. (1963). How to do things with words. Analysis (United Kingdom), 23(Suppl. 1), 58-64. https://doi.org/10.1093/analys/23.Suppl-1.58 